\title{
Analysing Solanum tuberosum L. Genetic Divergence using Molecular Marker Data
}

\author{
Anamika Verma ${ }^{1 *}$ and Dhirendra Singh ${ }^{2}$
}

\author{
${ }^{1}$ Department of Horticulture, Lovely Professional University, Phagwara, Punjab, India. \\ ${ }^{2}$ Department of Vegetable Science, College of Agriculture, G B Pant University of Agriculture \& Technology, Pantnagar, U.K. 263145, India. \\ *1e-mail id.: verma.anamika02@gmail.com
}

\begin{abstract}
Genetic polymorphism has important implications for the conservation and evolutionary studies among species as well as within genomes. Hence an enhanced understanding of intra-specific heterogeneity is anticipated which is and based on accurate database or unruffled by environmental conditions. In this context, molecular markers due to their simplicity and ubiquity have been used for genetic divergence studies of tetraploid potato. In the present study genetic diversity, marker attributes and population structure of 48 potato genotypes based on 20 SSR markers data were analysed which were able to successfully generate significant levels of DNA polymorphism to discriminate the experimental material. A total of 33 different loci were amplified that exhibited an average of 90 per cent polymorphism. The PIC value ranged from 0.11 to 0.70. PCR amplification exhibited genetic diversity was analyzed using program NTSYS-PC 2.21. Similarity coefficient or Jaccard coefficient were calculated using SIMQUAL program which varied from 0.32 to 0.92 and dendogram constructed using UPGMA cluster analysis ordered the populations of 48 genotypes into ten clusters. The maximum genetic similarity (0.92) was found between Pant Sel-09 and Pant Sel-09-04 and lowest (0.32) between Pant Sel-09-20 and Pant Sel-09-01. Most diverse groups found were cluster $X$ and cluster II thus, can be utilized as diverse parents in potato breeding programmes.
\end{abstract}

Keywords-DNA isolation; Genetic diversity; PCR; Potato; SSR.

\section{INTRODUCTION}

Improving skills is a prerequisite in today's technology driven world which needs researchers to stay abreast of the latest advancements in crop research, especially staple crops like potato (Solanum tuberosum L.). Potato is the most important non-cereal crop and a key component to address poverty and hunger sustaining food security especially in developing countries (Tillault and Yevtushenko, 2019). Moreover, potato is considered as the fourth most important food crop in the world having potential to deal with the challenges of combating malnutrition and reassuring nutritional food security to meet the demands of ever increasing population in developing countries (Ma et al., 2017). Being an important cash crop, it has potential to address farmer's distress by enabling them to increase their income, thus, depleting poverty by providing more nutrition and yield per unit area of land compared to major crops (Zaheer and Akhtar, 2016). According to Zaheer and Akhtar
(2016), on an average potato tuber contain $77 \%$ water, $20 \%$ carbohydrate, $3 \%$ protein, dietary fiber, vitamins and minerals. Potato covers major economic share in global agricultural market being a short duration crop with wide climate adaptability enabling its cultivation in diverse geographical borders. The worldwide demand for potato production requires constant development of new potato varieties, with improved yield, disease resistance and varied climatic resilience (Tillault and Yevtushenko, 2019). Potato production must be assured qualitatively and quantitatively at grower, processor and most importantly consumer level.

In this context, crop improvement strategy is of the utmost importance, can prove a valuable aid in both quantitative and qualitative breeding program employed for trait improvement prompting superior variety production in potato, which in turn demands wide germplasm collection, germplasm diversity know-about and their genetic relationships (Hameed et al., 2018). Many cultivated potato 
cultivars are autotetraploid $(2 \mathrm{n}=4 \mathrm{x}=48)$ with highly heterozygous genome having enormous genetic diversity. Potato has its origin centre in Andes of South America where diploid potato cultivars are also cultivated though they suffer from severe inbreeding depression and self-incompatibility (Xiaoyan et al., 2016). The evolutionary diversity of potato germplasm makes them excellent material for improving the narrow genetic base especially of cultivated potato providing enormous opportunity for breeders to choose best parents for proper breeding scheme and strategies (Anoumaa et al., 2017; Carputo et al., 2013). Genetic diversity among germplasm helps not only in choosing better performing say high yielding and resistant germplasm, but prompting them to be directly incorporated not only into breeding programmes (as a rule in conventional method) (Halterman et al., 2016; Dar et al., 2017), but also in molecular aided breeding (Carrasco et al., 2009). Where on one hand using conventional method during diversity analysis researcher is likely to misinterpretate the germplasm performance based on field data as it is directly affected by the environmental conditions, molecular marker on other hand are fully deprived of such limitation.

Molecular markers owing to their high resolution and accuracy in differentiating germplasm have become important tool in genetic diversity studies of agronomic and horticultural crops (Bered et al., 2005; Barandella et al., 2006). Among various marker techniques that are available, particularly promising are SSR markers (Simple Sequence Repeats), RFLP (Restriction Fragment Length Polymorphism), AFLP (Amplified Fragment Length Polymorphism) and ISSR (Inter- Simple Sequence Repeat) etc. (Xia et al., 2014; Saensuk et al., 2016; Dumhai et al., 2019; Wu et al., 2019). These SSRs or microsatellites are found throughout the nuclear genomes ranging from mono to hexa nucleotide in length among which di-, tri- and tetranucleotide repeats are most common choice for molecular genetic studies (Selkoe and Toonen, 2006). Different types of SSRs have been classified by source of development (Genomic SSRs, Genic SSSRs and Organellar (chloroplast and mitochondrial SSRs)), types of repeat sequence (Simple and compound with perfect and imperfect SSRs) and length of repeat motifs (Class I and II microsatellites) (Al-Samrai and Al-Kazaz, 2015). Microsatellites with tandem DNA repeats along with random genome distribution (throughout coding and non-coding regions), codominant nature, high polymorphism, high specificity with better reproducibility are promising for germplasm evaluation aiding diversity analysis and molecular assisted breeding (Qiu et al., 2006; Tabkhkar et al., 2012; Singh et al., 2013). As reported by various researchers a low quality DNA is enough for SSR markers for evaluating genetic diversity, moreover, if these markers could be associated with the resistance conferring trait (Barone, 2004; Gavrilenko et al., 2010), may furthermore assist in germplasm fingerprinting (Yang et al., 2015), genetic linkage mapping (Jian et al., 2017) and phylogenetic studies (Duan et al., 2018). Thus, SSRs markers have pivotal role in diversity analysis even for tetraploid species like potato offering new opportunities for selection of superior genotypes backing a sustained potato breeding program with main goal to obtain new cultivar exhibiting better yield and quality traits, along with biotic and abiotic stress resistance. The present study aimed at executing primary step of breeding program i.e. analyzing diversity of 48 potato genotypes based on SSR markers desired to provide the researchers with more options for designing breeding programs for producing superior potato cultivars.

\section{MATERIALS AND METHODS}

\section{Experimental material}

The molecular analysis was performed at Molecular lab of PCPGR (Pantnagar Center for Plant Genetic Resource), Department of Genetics and Plant Breeding, G. B. Pant University of Agriculture and Technology, Pantnagar, Uttarakhand in 2018. Pantnagar is geographically situated in the Tarai region at the foot hills of Himalayas at $29^{\circ} \mathrm{N}$ latitude and $79.3^{\circ} \mathrm{E}$ longitude and at an altitude of 243.83 meters above the mean sea level. The region has humid subtropical climate with the maximum temperature ranging from $30^{\circ} \mathrm{C}$ to $45^{\circ} \mathrm{C}$ in summer and least $3.7^{\circ} \mathrm{C}$ to $12.9^{\circ} \mathrm{C}$ in winter. The germplasm evaluated in this study consisted of 48 genotypes out of which 26 were developed through selection at Pantnagar named as Pant selection series and five of the germplasm consisted of advanced breeding lines i.e. Jseries collected from Pantnagar itself. The study also included seventeen potentially released Kufri varieties from CPRI (Central Potato Research Institute), Shimla (Table 1). 
Table 1. Detailed list of potato germplasm used in this present study.

\begin{tabular}{|c|c|c|c|}
\hline Sl. No. & Tentative genotypes name & City & Region/State/Counry \\
\hline 1. & Pant Sel-09-20 & Pantnagar & Uttarakhand, India \\
\hline 2. & Pant Sel-01-15 & Pantnagar & Uttarakhand, India \\
\hline 3. & Pant Sel-09-07 & Pantnagar & Uttarakhand, India \\
\hline 4. & Pant Sel-09-11 & Pantnagar & Uttarakhand, India \\
\hline 5. & Pant Sel-09-53 & Pantnagar & Uttarakhand, India \\
\hline 6. & Pant Sel-09-58 & Pantnagar & Uttarakhand, India \\
\hline 7. & Pant Sel-08-11 & Pantnagar & Uttarakhand, India \\
\hline 8. & Pant Sel-09-38 & Pantnagar & Uttarakhand, India \\
\hline 9. & Pant Sel-09-33 & Pantnagar & Uttarakhand, India \\
\hline 10. & Pant Sel-08-02 & Pantnagar & Uttarakhand, India \\
\hline 11. & Pant Sel-09-57 & Pantnagar & Uttarakhand, India \\
\hline 12. & Pant Sel-09-46 & Pantnagar & Uttarakhand, India \\
\hline 13. & Pant Sel-09-03 & Pantnagar & Uttarakhand, India \\
\hline 14. & Pant Sel-09-43 & Pantnagar & Uttarakhand, India \\
\hline 15. & Pant Sel-09 & Pantnagar & Uttarakhand, India \\
\hline 16. & Pant Sel-09-08 & Pantnagar & Uttarakhand, India \\
\hline 17. & Pant Sel-09-04 & Pantnagar & Uttarakhand, India \\
\hline 18. & Pant Sel-09-21 & Pantnagar & Uttarakhand, India \\
\hline 19. & Pant Sel-08-07-01(CT) & Pantnagar & Uttarakhand, India \\
\hline 20. & Pant Sel-09-01 & Pantnagar & Uttarakhand, India \\
\hline 21. & Pant Sel-09-55 & Pantnagar & Uttarakhand, India \\
\hline 22. & Pant Sel-09-50 & Pantnagar & Uttarakhand, India \\
\hline 23. & Pant Sel-15/5 & Pantnagar & Uttarakhand, India \\
\hline 24. & Pant Sel-09-19 & Pantnagar & Uttarakhand, India \\
\hline 25. & Pant Sel-01 & Pantnagar & Uttarakhand, India \\
\hline 26. & Pant Sel-09-18 & Pantnagar & Uttarakhand, India \\
\hline 27. & J-95-225 & Pantnagar & Uttarakhand, India \\
\hline 28. & $\mathrm{~J}-93-159$ & Pantnagar & Uttarakhand, India \\
\hline 29. & $\mathrm{~J}-97-242$ & Pantnagar & Uttarakhand, India \\
\hline 30. & $\mathrm{~J}-96-54$ & Pantnagar & Uttarakhand, India \\
\hline 31. & $\mathrm{~J}-96-288$ & Pantnagar & Uttarakhand, India \\
\hline 32. & Kufri Surya & Central Potato Research Institure & Shimla, H.P., India \\
\hline 33. & Kufri sutlej & Central Potato Research Institure & Shimla, H.P., India \\
\hline
\end{tabular}


International Journal of Environment, Agriculture and Biotechnology, 5(3)

May-Jun, 2020 / Available: https://ijeab.com/

\begin{tabular}{|c|l|l|l|}
\hline 34. & Kufri Arun & Central Potato Research Institure & Shimla, H.P., India \\
\hline 35. & Kufri Frysona & Central Potato Research Institure & Shimla, H.P., India \\
\hline 36. & Kufri Jawahar & Central Potato Research Institure & Shimla, H.P., India \\
\hline 37. & Kufri Bahar & Central Potato Research Institure & Shimla, H.P., India \\
\hline 38. & Kufri Pushkar & Central Potato Research Institure & Shimla, H.P., India \\
\hline 39. & Kufri Jyoti & Central Potato Research Institure & Shimla, H.P., India \\
\hline 40. & Kufri Gaurav & Central Potato Research Institure & Shimla, H.P., India \\
\hline 41. & Kufri Giriraj & Central Potato Research Institure & Shimla, H.P., India \\
\hline 42. & Kufri Himalini & Central Potato Research Institure & Shimla, H.P., India \\
\hline 43. & Kufri Chipsona-3 & Central Potato Research Institure & Shimla, H.P., India \\
\hline 44. & Kufri Chipsona-1 & Central Potato Research Institure & Shimla, H.P., India \\
\hline 45. & Kufri Chipsona-2 & Central Potato Research Institure & Shimla, H.P., India \\
\hline 46. & Kufri Ashoka & Central Potato Research Institure & Shimla, H.P., India \\
\hline 47. & Kufri Badshah & Central Potato Research Institure & Shimla, H.P., India \\
\hline 48. & Kufri Khyati & Central Potato Research Institure & Shimla, H.P., India \\
\hline
\end{tabular}

\section{Genomic DNA isolation}

The fresh and green leaves of 48 potato genotypes were collected and the genomic DNA was extracted by using the CTAB (cetyl trimethyl ammonium bromide) method of Doyle and Doyle (1990) with slight modifications (Deshmukh et al. 2007). Approximately, $2 \mathrm{~g}$ of leaf tissues was collected to extract the genomic DNA using the CTAB method. Genomic DNA was quantified using a NanoDrop spectrophotometer and quality of the genomic DNA was checked using electrophoresis on $1 \%$ agarose gel and later the samples stored at $-80{ }^{\circ} \mathrm{C}$. DNA concentration was quantified by using UV spectrophotometer and the OD (optical density) was measured at $260 \mathrm{~nm}$ for estimating the DNA concentration. The concentration relates to the OD and calculated by equation (DNA concentration $(\mu \mathrm{g} / \mu \mathrm{l})=\mathrm{OD}$ $260 \times 50 \times$ dilution factor/ 1000). Here, OD recorded at $260 / 280 \mathrm{~nm}$ to calculate the ratio OD206/OD280 where, a ratio of 1.8 is best for DNA preparation. DNA was diluted to50 $\mathrm{ng} / \mu \mathrm{l}$ and stored at $4^{\circ} \mathrm{C}$ for use in PCR, and concentrated stocks were stored at $-80^{\circ} \mathrm{C}$ for future use.

\section{PCR amplification \& Gel electrophoresis}

The molecular divergence study was performed using 20 SSR primers pairs obtained from various sources evenly distributed along potato genome (Ghislain et al., 2001, 2004, 2009; Feingold et al., 2005; Kawchuk et al., 1996; Melbourne et al., 1998; Provan et al., 1996; Moisan-Theiry et al., 2005) (Table 2). The Polymerase Chain Reaction (PCR) was performed in eppendorf thermocycler. Master Mix containing dNTP mix $(1.5 \mu \mathrm{L})$, Taq DNA polymerase $(0.1 \mu \mathrm{L})$, forward and reverse primer $1.5 \mu \mathrm{L}(50 \mathrm{ng} / \mu \mathrm{L})$, reaction buffer A $2 \mu \mathrm{L}(10 \mathrm{X})$ and deionized water $(6.6 \mu \mathrm{L})$ was prepared. The master mix was then distributed in each tube $(11.5 \mu \mathrm{L}$ each) and finally $1 \mu \mathrm{L}$ of different template DNA was added in each tube. The mixture was gently mixed and centrifuged for ten seconds. The PCR amplification was achieved in thermo cycler (eppendorf thermocycler). The amplification cycles used were initial denaturation at $94{ }^{\circ} \mathrm{C}$ for 3 minutes, followed by 35 cycles of denaturation at $94^{\circ} \mathrm{C}$ for 1 minute, annealing at $60-65{ }^{\circ} \mathrm{C}$ for $45-50 \mathrm{sec}$ and synthesis at $72{ }^{\circ} \mathrm{C}$ for 1 minute culminating into final extension step of 5-7 minutes at $72^{\circ} \mathrm{C}$. Later gel electrophoresis was done where the amplified DNA product along with molecular marker was run on $2.5 \%$ agarose gel electrophoresis and visualized under U.V. transilluminator using gel documentation system. 
International Journal of Environment, Agriculture and Biotechnology, 5(3)

May-Jun, 2020 / Available: https://ijeab.com/

Table 2. Detailed description of primer sequences of SSR marker for potato

\begin{tabular}{|c|c|c|c|c|c|c|c|}
\hline S.No. & $\begin{array}{l}\text { SSR } \\
\text { Primer }\end{array}$ & $\begin{array}{l}\text { Repeat } \\
\text { motifs }\end{array}$ & $\begin{array}{l}\text { Forward sequence(5'--3') } \\
\text { Reverse sequence (3'--5') }\end{array}$ & $\begin{array}{c}\text { Map } \\
\text { location }\end{array}$ & $\begin{array}{l}\text { Annealing } \\
\text { temp. }\left({ }^{\circ} \mathrm{C}\right)\end{array}$ & Size (bp) & Source \\
\hline 1. & STG0001 & (CT)n & $\begin{array}{l}\text { 5'CAGCCAACATTTGTACCCCT3' } \\
\text { 3'ACCCCCACTTGCCATATTTT5' }\end{array}$ & $\mathrm{X} 1$ & 58 & $137-163$ & $\begin{array}{l}\text { Ghislain et al., } \\
2009\end{array}$ \\
\hline 2. & STG0016 & $(\mathrm{AGA}) \mathrm{n}$ & $\begin{array}{l}\text { 5’AGCTGCTCAGCATCAAGAGA3' } \\
\text { 3'ACCACCTCAGGCACTTCATC5', }\end{array}$ & I & 55 & $137-174$ & $\begin{array}{l}\text { Ghislain et al., } \\
2004\end{array}$ \\
\hline 3. & STI0030 & (ATT)n & $\begin{array}{l}\text { 5'TTGACCCTCCAACTATAGATTCTTA3' } \\
\text { 3'TGACAACTTTAAAGCATATGTCAGC5', }\end{array}$ & XII & 58 & $94-137$ & $\begin{array}{l}\text { Feingold et al., } \\
2005\end{array}$ \\
\hline 4. & STI0032 & $(\mathrm{GGA}) \mathrm{n}$ & $\begin{array}{l}\text { 5'TGGGAAGAATCCTGAAATGG3' } \\
\text { 3'TGCTCTACCAATTAACGGCA5' }\end{array}$ & V & 61 & $127-138$ & $\begin{array}{l}\text { Feingold et al., } \\
2005\end{array}$ \\
\hline 5. & STI0036 & $(\mathrm{AC}) \mathrm{n}$ & $\begin{array}{l}\text { 5'GGACTGGCTGACCATGAACT3' } \\
\text { 3'TTACAGGAAATGCAAACTTCG5', }\end{array}$ & II & 55 & $129-164$ & $\begin{array}{l}\text { Feingold et al., } \\
\text { 2005; Ghislain et } \\
\text { al., } 2009\end{array}$ \\
\hline 6. & STI0003 & $(\mathrm{ACC}) \mathrm{n}$ & $\begin{array}{l}\text { 5'ACCATCCACCATGTCAATGC3' } \\
\text { 3'CTCATGGATGGTGTCATTGG5' }\end{array}$ & VIII & 60 & $137-188$ & $\begin{array}{l}\text { Feingold et al., } \\
\text { 2005; Ghislain et } \\
\text { al., } 2009\end{array}$ \\
\hline 7. & STI0014 & $(\mathrm{TGG}) \mathrm{n}$ & $\begin{array}{l}\text { 5'AGAAACTGAGTTGTGTTTGGGA3', } \\
\text { 3’TCAACAGTCTCAGAAAACCCTCT5', }\end{array}$ & IX & 54 & $127-157$ & $\begin{array}{l}\text { Feingold et al., } \\
\text { 2005; Ghislain et } \\
\text { al., } 2009\end{array}$ \\
\hline 8. & STI0023 & $(\mathrm{CAG}) \mathrm{n}$ & $\begin{array}{l}\text { 5'GCGAATGACAGGACAAGAGG3' } \\
\text { 3'TGCCACTGCTACCATAACCA5', }\end{array}$ & $\mathrm{X}$ & 61 & $172-245$ & $\begin{array}{l}\text { Feingold et al., } \\
\text { 2005; Ghislain et } \\
\text { al., } 2009\end{array}$ \\
\hline 9. & STM1104 & (TCT)n & $\begin{array}{l}\text { 5'TGATTCTCTTGCCTACTGTAATCG3' } \\
\text { 3'CAAAGTGGTGTGAAGCTGTGA5' }\end{array}$ & VIII & 53 & 178-199 & $\begin{array}{l}\text { Melborne et al, } \\
1998\end{array}$ \\
\hline 10. & STM0040 & $(\mathrm{AT}) \mathrm{n}$ & $\begin{array}{l}\text { 5'GCAATAATGGCCAACACTTC3' } \\
\text { 3'TGGGAAATGTTAGTCAAAAATAGC5' }\end{array}$ & VI & 58 & $90-120$ & $\begin{array}{l}\text { Ghislain et al., } \\
2004\end{array}$ \\
\hline 11. & STM2005 & $\begin{array}{c}\text { (CTGTTG } \\
\text { )n }\end{array}$ & $\begin{array}{l}\text { 5'TTTAAGTTCTCAGTTCTGCAGGG3' } \\
\text { 3'GTCATAACCTTTACCATTGCTGG5', }\end{array}$ & XI & 60 & $160-193$ & $\begin{array}{l}\text { Moisan-Theiry et } \\
\text { al., } 2005\end{array}$ \\
\hline 12. & STI0012 & (ATT)n & $\begin{array}{l}\text { 5'GAAGCGACTTCCAAAATCAGA3' } \\
\text { 3'AAAGGGAGGAATAGAAACCAAAA5' }\end{array}$ & IV & 56 & $183-234$ & \begin{tabular}{|l|} 
Feingold et al., \\
2005
\end{tabular} \\
\hline 13. & STGBSS & (TCT)n & $\begin{array}{l}\text { 5'AATCGGTGATAAATGTGAATGC3' } \\
\text { 3'ATGCTTGCCATGTGATGTGT5' }\end{array}$ & VIII & 53 & $121-150$ & $\begin{array}{l}\text { Provan et al., } \\
\text { 1996; Ghislain et } \\
\text { al., } 2009\end{array}$ \\
\hline 14. & STM5121 & (TGT)n & $\begin{array}{l}\text { 5'CACCGGAATAAGCGGATCT3' } \\
\text { 3'TCTTCCCTTCCATTTGTCA5' }\end{array}$ & XII & 48 & 297-309 & $\begin{array}{l}\text { Ghislain et al., } \\
2009\end{array}$ \\
\hline 15. & STM5127 & (TCT)n & $\begin{array}{l}\text { 5’TTCAAGAATAGGCAAAACCA3' } \\
\text { 3'CTTTTTCTGACTGAGTTGCCTC5' }\end{array}$ & I & 55 & $248-291$ & $\begin{array}{l}\text { Ghislain et al., } \\
2009\end{array}$ \\
\hline
\end{tabular}


International Journal of Environment, Agriculture and Biotechnology, 5(3)

May-Jun, 2020 / Available: https://ijeab.com/

\begin{tabular}{|c|c|c|l|c|c|c|l|}
\hline 16. & STM1031 & (AT)n & $\begin{array}{l}\text { 5'TGTGTTTGTTTTCTGTAT-3' } \\
\text { 3'TTCAGTCAACTCCTGTTGCG-5' }\end{array}$ & V & 55 & 236-301 & $\begin{array}{l}\text { Milbourne et al., } \\
1998\end{array}$ \\
\hline 17. & STM1058 & (ATT)n & $\begin{array}{l}\text { 5'ACAATTTAATTCAAGAAGCTAGG3' } \\
\text { 3'CCAAATTTGTATACTTCAATATGA5' }\end{array}$ & III & 55 & $130-139$ & $\begin{array}{l}\text { Milbourne et al., } \\
1998\end{array}$ \\
\hline 18. & STM1045 & (ATC)n & $\begin{array}{l}\text { 5'GAAGTTTTATCAGAATCC3' } \\
\text { 3'ATCACCTCATCAGCAATC5' }\end{array}$ & II,III & 55 & $130-148$ & $\begin{array}{l}\text { Ghislain et al., } \\
2001\end{array}$ \\
\hline 19. & STM1050 & (TA)n & $\begin{array}{l}\text { 5'GTACATATATACAATTATCTAACCG3' } \\
\text { 3'TTCTCTATGTTAGGCTAGAGTG5' }\end{array}$ & VI & 54 & $150-190$ & $\begin{array}{l}\text { Ghislain et al., } \\
2004\end{array}$ \\
\hline 20. & STM0019 & $\begin{array}{l}\text { (AT)n } \\
\text { (GT)n }\end{array}$ & $\begin{array}{l}\text { 5'AATAGGTGTACTGACTCTCAATG3' } \\
\text { 3'TTGAAGTAAAAGTCCTAGTATGTG5' }\end{array}$ & VI & 47 & $99-206$ & $\begin{array}{l}\text { Kawchuk et al., } \\
1996 ; \\
1998\end{array}$ \\
\hline
\end{tabular}

\section{SSR data analysis}

Amplified SSR profile of all the genotypes with each primer were documented using gel documentation system. DNA for each fragment profiles was scored in a binary fashion with 0 indicating absence and 1 indicating presence of a band for each SSR locus. Primers with null allele where an amplification product could not be detected were not considered in the analysis. Principal Component analysis was done using the software NTSYSpc version 2.2 whereas marker attributes like allele frequency (FA), allele number, polymorphic information content (PIC), Gene diversity, Effective multiplex ratio (EMR) and marker index (MI) were estimated by using the Power Marker statistics software version 3.25 (Liu and Muse 2005). Allele frequency was calculated as nu/N, where nu is number of alleles present and $\mathrm{N}$ is total number of genotypes (Dar et al., 2017). The PIC detects an allelic variability and was calculated as according to Botstein et al. (1980). Marker index was calculated as product of EMR and PIC (Varshney et al., 2007). Further the binary data were used to calculate genetic similarities based on Jaccard coefficients among the isolates using SIMQUAL program (Jaccard, 1908) and on the basis of these coefficients, dendogram was constructed using UPGMA (Unweighted Pair Group Mean Average) method to determine the genetic relationship of potato genotypes.

\section{RESULTS AND DISSCUSSION}

\section{SSR polymorphism}

A total of 20 SSR primers used for distinguishing potato genotypes were selected based on the quality criteria, genome coverage, and locus- specific information content as studied by Ghislain et al., (2009). Out of twenty SSR primers fourteen primers were polymorphic and six primers were found monomorphic (STI0003, STM0040, STM1031, STM1058, STM1045 and STM0019). A total of 33 different loci were amplified that exhibited 90 per cent polymorphism. The PIC value ranged from 0.11 to 0.70 . Analysis for polymorphism in SSR markers has been provided in Table 3. All the loci amplified by the primer which were found to be polymorphic varied in size from <100bp to >300bp. Maximum number of four polymorphic bands were amplified using primer STM2005 where primers STG0016, STI0023, STI0014 and STM5127 amplified three bands each. The PCR profile of primer STM2005 and STG0016 provided in Fig. 1 and 2. Primer STM2005, STG0016, STI0023 having high polymorphism value were the most informative among multi loci SSR markers used, capable of distinguishing all the varieties studied. Primer STM2005 (highest 4 alleles) and STG0016 (3 alleles) could distinguish all the varieties except Pant Sel-09-57 and J-96-288. Primer STI0014 was comparatively less informative and could distinguish only 40 genotypes. Primer STM2005, STM0016 and primer STI0030 gave $0.70,0.65$ and 0.14 PIC respectively in our study where the same primer gave 0.78 , 0.79 and 0.83 PIC respectively in study done by Solano et al. (2013), where primer STM0016 amplified highest number of loci. This may possibly due to difference in study material with varied genetic basis or due to narrow genetic basis of few germplasm as they all are derived through selection and few released varieties have one or other genotypes in their parentage. The number of allele ranged from 1 to 4 with an average of 2.0 as compared to other studies which may be due to lesser number of markers used. 
Table 3. A summary of data analysis of polymorphism shown by SSR markers.

\begin{tabular}{|c|c|c|c|c|c|c|c|c|c|c|c|c|c|c|}
\hline Sno & Marker & $\begin{array}{l}\text { Allele } \\
\text { Freque } \\
\text { ny }\end{array}$ & $\begin{array}{l}\text { Allele } \\
\text { no. }\end{array}$ & $\begin{array}{l}\text { Gene } \\
\text { diversit } \\
\text { y }\end{array}$ & \begin{tabular}{|l|} 
Amplificat \\
ion product \\
size
\end{tabular} & 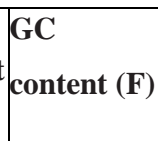 & $\begin{array}{l}\text { GC } \\
\text { content } \\
(\mathbf{R})\end{array}$ & $\begin{array}{l}\text { Anneal } \\
\text { ng } \quad \mathrm{T} \\
\left({ }^{\circ} \mathrm{C}\right)\end{array}$ & \begin{tabular}{l|l} 
li & Polymorp \\
Tmhic bands
\end{tabular} & $\begin{array}{l}\text { Monom } \\
\text { or phic } \\
\text { bands }\end{array}$ & MI & EMR & $\begin{array}{l}\text { Polymorp } \\
\text { hism (\%) }\end{array}$ & $\begin{array}{l}\text { PIC } \\
\text { value }\end{array}$ \\
\hline 1. & STM5127 & 0.75 & 3 & 0.35 & $250-350$ & 35 & 45 & 60.0 & 3 & 0 & 1.16 & 2 & 100 & 0.58 \\
\hline 2. & STI0030 & 0.92 & 1 & 0.15 & 150 & 36 & 36 & 62.0 & 1 & 0 & 0.42 & 3 & 100 & 0.14 \\
\hline 3. & STG0001 & 0.88 & 2 & 0.19 & 150 & 50 & 45 & 66.0 & 2 & 0 & 0.75 & 3 & 100 & 0.25 \\
\hline 4. & STG0016 & 0.78 & 3 & 0.44 & $200-250$ & 50 & 55 & 63.5 & 3 & 0 & 1.95 & 3 & 100 & 0.65 \\
\hline 5. & STI0012 & 0.83 & 2 & 0.22 & $150-200$ & 43 & 35 & 63.2 & 1 & 1 & 0.51 & 3 & 50 & 0.17 \\
\hline 6. & STI0032 & 0.75 & 2 & 0.32 & 175 & 45 & 45 & 63.4 & 2 & 0 & 0.75 & 3 & 100 & 0.25 \\
\hline 7. & STM2005 & 0.67 & 4 & 0.48 & $125-250$ & 43 & 43 & 61.0 & 4 & 0 & 2.20 & 3 & 100 & 0.70 \\
\hline 8. & STGBSS & 0.66 & 2 & 0.45 & $150-175$ & 36 & 45 & 64.0 & 2 & 0 & 0.70 & 2 & 100 & 0.35 \\
\hline 9. & STM1104 & 0.75 & 2 & 0.27 & $180-200$ & 42 & 48 & 63.5 & 2 & 0 & 0.42 & 2 & 100 & 0.21 \\
\hline 10. & STM5121 & 0.94 & 1 & 0.12 & 175 & 50 & 45 & 66.0 & 1 & 0 & 0.33 & 3 & 100 & 0.11 \\
\hline 11. & STI0023 & 0.67 & 2 & 0.44 & $150-250$ & 55 & 50 & 64.0 & 3 & 0 & 1.63 & 3 & 100 & 0.55 \\
\hline 12. & STI0014 & 0.86 & 2 & 0.23 & $150-250$ & 41 & 43 & 62.5 & 3 & 0 & 1.20 & 3 & 100 & 0.40 \\
\hline 13. & STI0036 & 0.89 & 2 & 0.19 & $150-200$ & 55 & 38 & 63.0 & 2 & 0 & 0.78 & 3 & 100 & 0.26 \\
\hline 14. & STI1050 & 0.78 & 2 & 0.31 & $150-200$ & 28 & 41 & 52.5 & 2 & 0 & 0.75 & 3 & 100 & 0.25 \\
\hline
\end{tabular}

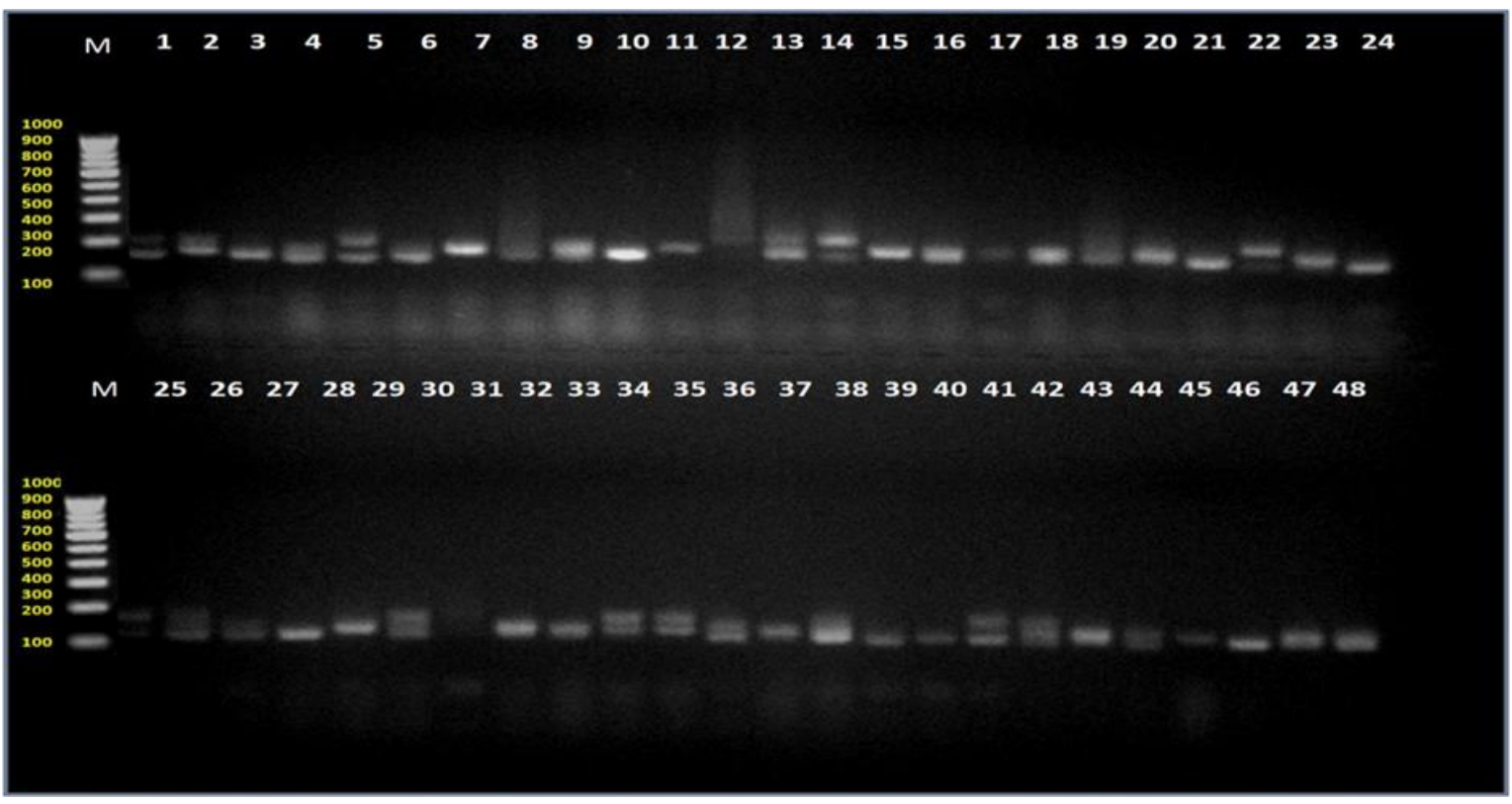

Fig.1. Amplification pattern of primer STM2005 


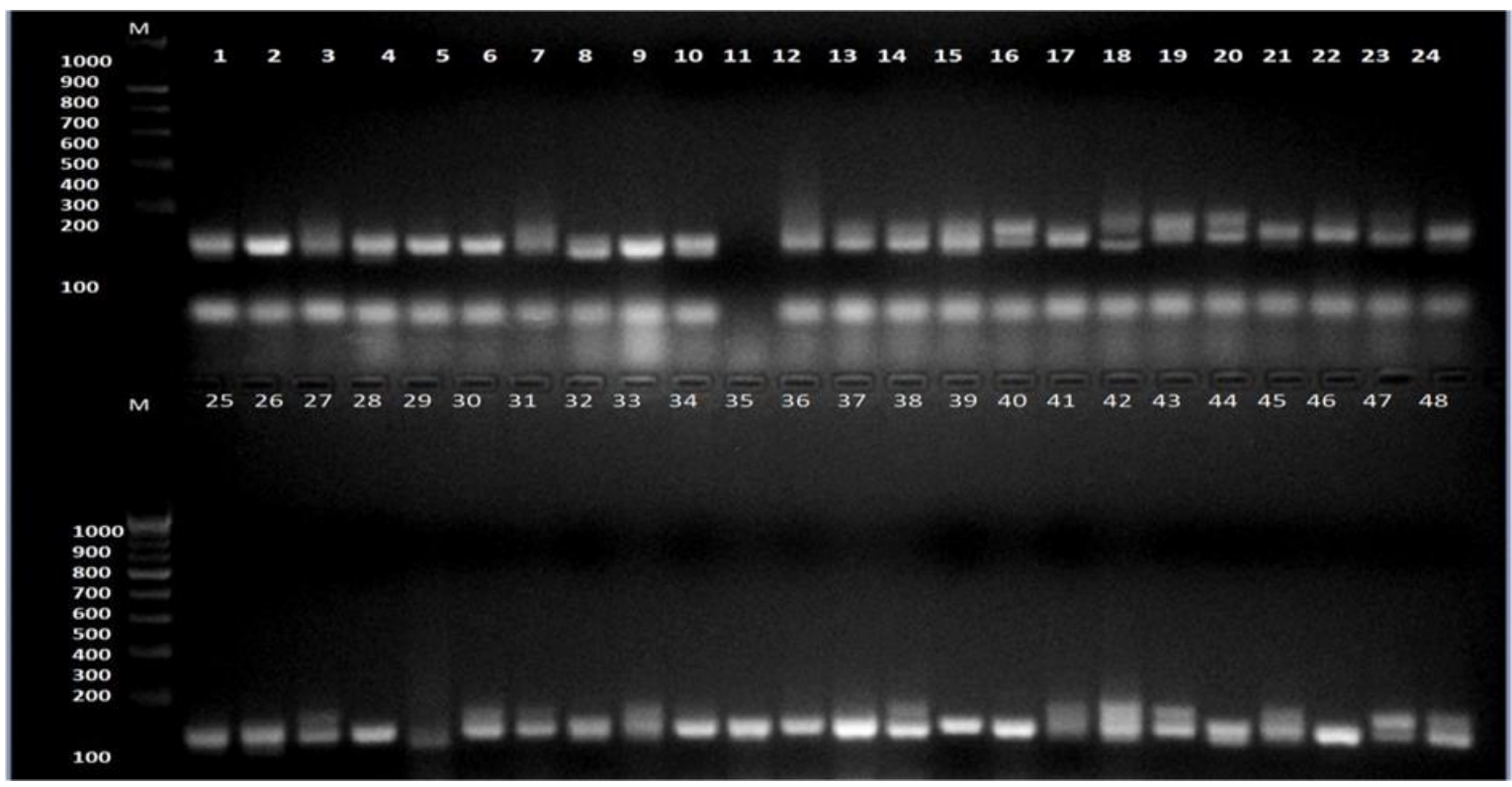

Fig.2. Amplification pattern of primer STG0016

According to Demeke et al. (1993), identification across database becomes easy once a fixed set of primer combination were taken in consideration. Present study in which SSR amplified a total of 33 different loci that exhibited 90 per cent polymorphism gave a better insight to which genotype are genetically more diverse. Favoretto et al. (2011) also found SSRs to generate three to five amplified loci. Similar results were reported by Komy et al. (2012) and Sharma et al. (2014). Many researchers (Demeke et al., 1993; Ghislain et al., 1999) have already differentiated 100 commercial potato cultivars with only twelve specific primers producing more DNA amplified polymorphism. The reported heterozygosity across screened genotypes suggested the genetic material that are distantly related and superior, can further be introduced as parents in breeding programmes (Wang et al., 2017; Wu et al., 2019).

\section{Genetic diversity analysis}

Based on the SSR marker data the Jaccard's similarity coefficients were estimated between pair of genotypes. The similarity coefficient was found to vary from 0.32 to 0.92 . The highest value for genetic similarity (0.92) was found between Pant Sel-09 and Pant Sel-09-04 followed by both Pant Sel-09-04 and Kufri Jyoti with Kufri Jawahar (0.91), Pant Sel-09-11 and J-95-225 (0.91), Kufri Khyati and Kufri Badshah (0.91) and Pant Sel-09-08 and Pant Sel-09-04 (0.91). The lowest similarity value (0.32) was found between Pant Sel-09-20 and Pant Sel-09-01 followed by Pant Sel-09-
57 and Pant Sel-01 (0.35), Pant Sel-09-20 and Pant Sel-15/5 (0.36) and Pant Sel-09-20 and Pant Sel-09-57 (0.38). This analysis suggests the varied germplasm collection with least to highest genetic similarity among them where high similarity suggests the possibility of germplasm belonging to same geographical area or involvement of any one similar parent in the case of Kufri varieties. Whereas, the least similar genotypes provides us with the opportunity to further utilize them in breeding program.

\section{Cluster analysis}

UPGMA based on Jaccard's similarity matrix of SSR markers ordered the populations of 48 genotypes into a single big group further dividing into ten clusters (Fig. 3). The biggest clusters were cluster IV and cluster II with maximum genotypes. Cluster II consisted of ten genotypes viz. Pant Sel-09-07, J-96-288, Pant Sel-09-11, J-95-225, Pant Sel-09-53, Pant Sel-09-46, Pant Sel-09-58, Pant Sel-09-38, Pant Sel-08-02 and Kufri Bahar. The largest cluster IV consisted of twelve genotypes viz. Pant Sel-09, Pant Sel-0904, Kufri Jawahar, Kufri Jyoti, Kufri Chipsona-1, Pant Sel08-07-01(CT), Kufri Chipsona-3, Kufri Pushkar, Kufri Giriraj, Kufri Himalini, Pant Sel-09-08 and Pant Sel-09-21 which varied between very low to very high yielding types (Table 4). Cluster I and cluster II showed similarity of 65 to 75 per cent where, Cluster II, III, IV and V had 70 to 74 per cent similarity between them. Cluster VI and VII was found to have about 60 to 71 per cent similarity with cluster I, II, 
III, IV and V whereas Cluster VIII, IX and X were found having 51 to 58 per cent similarity between them. The most diverse groups found were Cluster $\mathrm{X}$ and cluster II followed by cluster IX and III with Cluster II which clearly reveals that choosing parents/genotypes from these diverse clusters may produce heterosis in segregating generations which could be utilized further for development of good and promising hybrids. In cluster analysis, all 5 advanced breeding lines or $\mathrm{J}$ - series scattered in five different clusters indicating presence of sufficient variability among them. Genotypes belonging to Pant-series were also found scattered in different group along with low to high yielding and late blight susceptible to resistant Kufri varieties, which are similar to the findings of Demeke et al. (1993) and Grover et al. (2009).

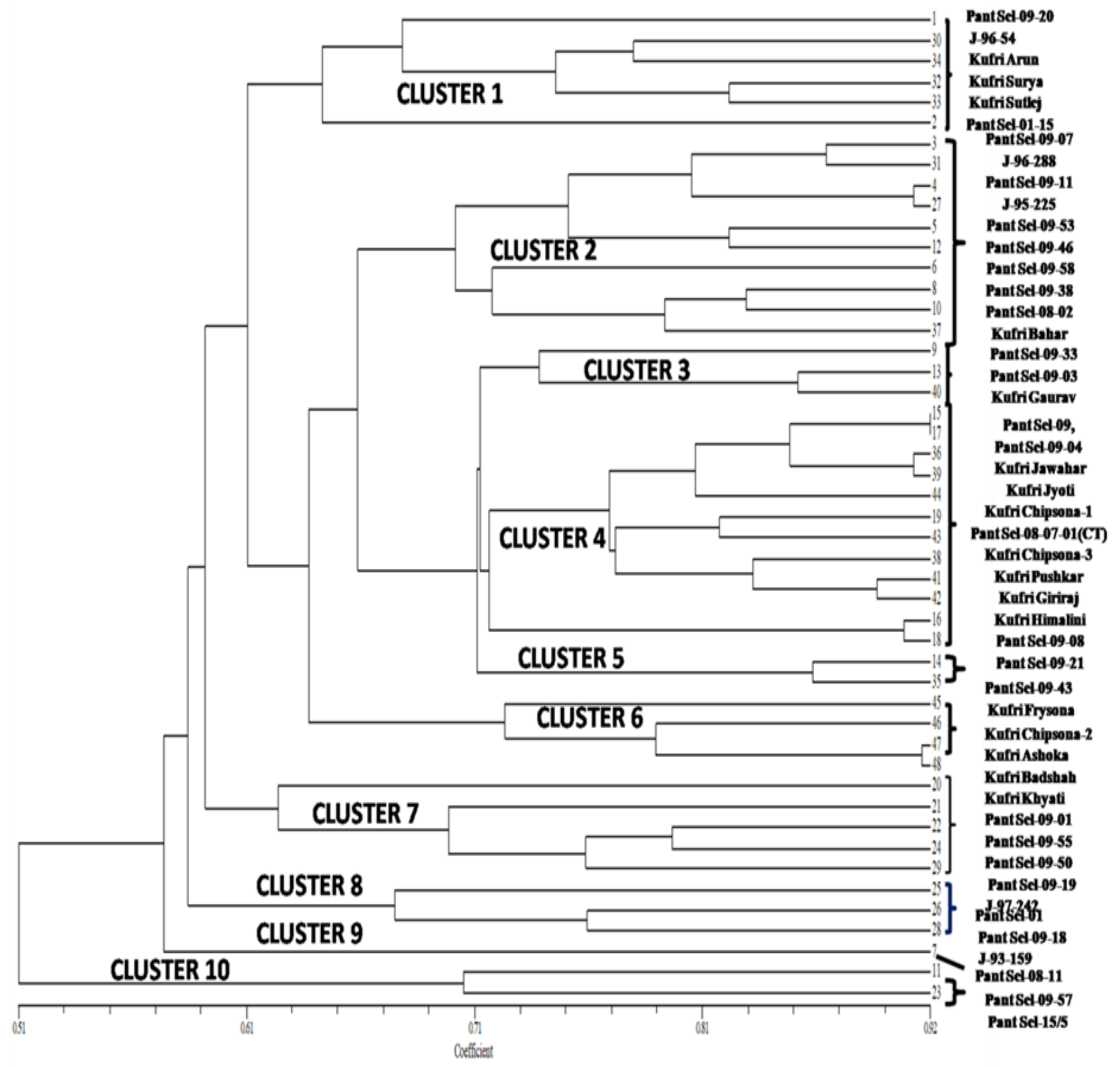

Fig.3. Dendrogram illustrating the phylogenetic relationship among 48 potato genotypes based on UPGMA cluster analysis. 
International Journal of Environment, Agriculture and Biotechnology, 5(3)

May-Jun, 2020 / Available: https://ijeab.com/

Table 4. Distribution pattern of 48 potato genotypes on the basis of UPGMA cluster analysis.

\begin{tabular}{|c|c|l|}
\hline Clusters Number & No. of genotypes & \multicolumn{1}{|c|}{ Genotypes } \\
\hline I & 6 & Pant Sel-09-20, J-96-54, Kufri Arun, Kufri Surya, Kufri Sutlej and Pant Sel-01-15 \\
\hline II & 10 & $\begin{array}{l}\text { Pant Sel-09-07, J-96-288, Pant Sel-09-11, J-95-225, Pant Sel-09-53, Pant Sel-09-46, } \\
\text { Pant Sel-09-58, Pant Sel-09-38, Pant Sel-08-02 and Kufri Bahar }\end{array}$ \\
\hline III & 3 & Pant Sel-09-33, Pant Sel-09-03 and Kufri Gaurav \\
\hline IV & 12 & $\begin{array}{l}\text { Pant Sel-09, Pant Sel-09-04, Kufri Jawahar, Kufri Jyoti, Kufri Chipsona-1, Pant Sel-08- } \\
\text { 07-01(CT), Kufri Chipsona-3, Kufri Pushkar, Kufri Giriraj, Kufri Himalini, Pant Sel- } \\
\text { 09-08 and Pant Sel-09-21 }\end{array}$ \\
\hline V & 2 & Pant Sel-09-43 and Kufri Frysona. \\
\hline VI & 4 & Kufri Chipsona-2, Kufri Ashoka, Kufri Badshah and Kufri Khyati \\
\hline VII & 5 & Pant Sel-09-01, Pant Sel-09-55, Pant Sel-09-50, Pant Sel-09-19 and J-97-242 \\
\hline VIII & 3 & Pant Sel-01, Pant Sel-09-18 and J-93-159 \\
\hline IX & 1 & Pant Sel-08-11 \\
\hline X & 2 & Pant Sel-09-57and Pant Sel-15/5 \\
\hline
\end{tabular}

Kufri Jyoti and K. Jawahar shared the same cluster IV which is likely because $\mathrm{K}$. Jyoti is included in the parentage of K. Jawahar. However, K. Chipsona -3 having K. Chipsona-2 in parentage were found in different groups. This observation can explain the poor correlation among coancestries and performance of the progeny. Kufri Jawahar, Kufri Chipsona-1, Kufri Chipsona-3 (all late blight resistant varieties) along with Kufri Jyoti, Kufri Pushkar, Kufri Giriraj, Kufri Himalini (moderately susceptible to late blight resistant variety) belonged to cluster IV. It is likely that other genotypes viz. Pant Sel-08-07-01(CT), Pant Sel-09, Pant Sel09-04, Pant Sel-09-08 and Pant Sel-09-21, belonging to the same cluster could confer resistance to late blight disease. However, late blight resistant varieties namely Kufri Badshah, K. Chipsona-2 and K. Khyati (field resistant) shared common cluster VI along with a late blight susceptible variety K. Ashoka. Although, they all were high yielding types and shown field resistant to blight disease which is similar to findings of Rocha et al. (2010), Tiwari et al. (2013) and Wang et al. (2017). Some of the Kufri varieties were grouped in same cluster even though they were bred from parent of wide genetic base with possible reason may be that these varieties were developed with the main aim of high yield under similar agro-climatic conditions of sub-topical plains. The genotypes viz. Pant Sel09-20 and Pant Sel-09-01, Pant Sel-09-20 and Pant Sel-15/5 and Pant Sel-09-20 and Pant Sel-09-57 with low genetic similarity can be used for further research.

Therefore, geographical diversity of the material alone would not help in selection of genetically divergent parents. For example during field trial, genotypes namely Pant Sel-09-38, Kufri Frysona, Kufri Himalini, Pant Sel-0904, Pant Sel-08-11, Kufri Pushkar, Pant Sel-09-50 and Pant Sel-09-43 were the best yielding genotypes but during molecular analysis, they all belonged to different clusters along with low yielding genotypes. Moreover, germplasm namely Pant Sel- 08-02, Pant Sel- 09-04, Pant Sel-09-43, Pant Sel-09-20, Pant Sel-09-11, Kufri Badshah, Kufri Ashoka, Kufri Chipsona-1 and Kufri Chipsona-2 showed high to moderate field resistance to late blight disease but no clear cut grouping was observed in resistant and susceptible genotypes by SSR primers as compared to field data indicating limited or low kinship relationship between morphological and molecular data among forty eight potato genotypes. This observation confirms that divergence is at intron and exon level both, making markers important for new hybrid development programme via combining distantly related genotypes. Molecular marker led cluster analysis provided an insight to marker's potential to carry out more comprehensive diversity analysis (Barandella et al. 2006; Wang et al. 2017; Duan et al. 2018; Dumhai et al. 2019). 


\section{CONCLUSION}

Evaluation of the genetic diversity of 48 potato genotypes based on 20 SSR markers gave clear idea about the genetic relationship among genotypes which resulted into grouping on the basis of the genetic distance among them aiding to deep knowledge about genetic makeup of genotypes. On the basis of PCR amplification various distantly related genotypes were identified. From this study, it may be concluded that significant diversity and variability was present among the genotypes and divergence analysis using SSR markers was proved to be better than morphological data for discrimination among genotypes. It is clear that microsatellites offer an effective means of analysing genetic distance between potato varieties which are especially useful for potato breeding program.

\section{REFERENCES}

[1] Anoumaa, M., Yao, N.K., Kouam, E.B., Kanmegne, G., Machuka, E., Osama, S., Nzuki, I. et al. (2017). Genetic diversity and core collection of potato (Solanum tuberosum L.) cultivars from Cameroon as revealed by SSR markers. American Journal of Potato Research. https://doi.org/10.1007/s12230-017-9584-2.

[2] Al-Samarai, F.R. \& Al-Kazaz, A.K.A. (2015). Molecular markers: An introduction and applications. European Journal of Molecular Biotechnology 9(3): 118-130. https://doi.org/10.13187/ejmb.2015.9.118.

[3] Barandalla, L., Galarreta, J.I.R. \& Ritter, E.R. (2006). Molecular analysis of local potato cultivars from Tenerife Island using microsatellite markers. Euphytica 152:283-291. https://doi.org/10.1007/s10681-006-9215-3.

[4] Barone, A. (2004). "Molecular Marker-Assisted Selection for Potato Breeding." American Journal of Potato Research 81(2): 111-117. https://doi.org/10.1007/bf02853608.

[5] Bered, F., Terra, T.F., Spellmeier, M. \& Neto, J.F.B. (2005). Genetic variation among and within sweet corn populations detected by RAPD and SSR markers. Crop Breeding and Applied Biotechnology 5: 418-425. http://www.sbmp.org.br/cbab/siscbab/uploads/bd6b8337-51fab952.pdf.

[6] Botstein, D., White, R.L., Skolnick, M. \& Davis, R.W. (1980). Construction of a genetic linkage map in man using restriction fragment length polymorphisms. American Journal of Human Genetics 32:314-331. https://www.ncbi.nlm.nih.gov/pmc/articles/PMC1686077/.

[7] Carrasco, A., Chauvin, J.E., Trognitz, B., PAwlak, A., RubioCovarruvias, O. \& Zimnoch-Guzowska, E. (2009). "MarkerAssisted Breeding for disease resistance in potato". Potato Research 52 (3): 245-248. https://doi.org/10.1007/s11540-0099132-7/.

ISSN : 2456-1878

https://dx.doi.org/10.22161/ijeab.53.29
[8] Carputo, D., Alioto, D., Aversano, R., Garramone, R., Miraglia, V., Villano, C. \& Frusciante, L. (2013). Genetic diversity among potato genotypes as revealed by phenotypic resistances and SSR markers. Plant Genetic Resource: Characterization and Utilization 11(2):131-139. https://doi.org/10.1017/S1479262112000500.

[9] Dar, A.A., Mahajan, R., Lay, P. \& Sharma, S. (2017). Genetic diversity and population structure of Cucumis sativus L. by using SSR markers. 3 Biotech 7:307. https://doi.org/10.1007/s13205-017-0944-x.

[10] Deshmukh, V.P., Thakare, P.V., Chaudhari, U.S. \& Gawande, P.A. (2007). A simple method of genomic DNA from fresh and dry leaves of Terminalia arjuna (Roxb.) Wright and Argot. Electronic Journal of Biotechnology 10(3). https://www.ejbiotechnology.info/content/vol10/issue3/full/5/.

[11] Demeke, T., Lynch, D.R., Kawchuck, L.M., Kozub, G.C. \& Armstrong, J.D. (1993). Genetic diversity of potato determined by random amplified polymorphic DNA analysis. Plant Cell Reports 15: 662-667. https://doi.org/10.1007/BF00231920.

[12] Duan, Y., Liu, J., Xu, J., Bian, C., Duan, S. \& Pang, W. (2018). DNA Fingerprinting and Genetic Diversity Analysis with Simple Sequence Repeat Markers of 217 Potato Cultivars (Solanum tuberosumL.) in China. American Journal of Potato Research 96: 21-32. https://doi.org/10.1007/s12230-018-9685$\underline{6}$.

[13] Doyle, J.J. \& Doyle, J.L. (1990) Isolation of plant DNA .from fresh tissues. Focus 12: 13-15.

[14] Dumhai, R., Wanchana, S., Saensuk, C., Choowongkomon, K, Mahatheeranont, S., Kraithong, T., Toojinda, T., Vanavichit, A. \& Arikit, S. (2019). Discovery of a novel CnAMADH2 allele associated with higher levels of 2-acetyl-1-pyrroline (2AP) in yellow dwarf coconut (Cocos nucifera L.). Scientia Horticulturae 243:490-497. https://doi.org/10.1016/j.scienta.2018.09.005.

[15] Favoretto, P., Veasey, E.A. \& Melo, P.C. (2011). Molecular characterization of potato cultivars using SSR markers. Horticlturae Brasiliense $29 \quad$ (4): $\quad 542-545$. https://doi.org/10.1590/S0102-05362011000400017.

[16] Feingold, S., Lloyd, J., Norero, N., Bonierbale, M. \& Lorenzen, J. (2005). Mapping and characterization of new EST-derived microsatellites for potato (Solanum tuberosum L.). Theoretical and Applied Genetics 111:456-466. https://doi.org/10.1007/s00122-005-2028-2.

[17] Gavrilenko, T., Antonova, O., Ovchinnikova, A., Novikova, L., Krylova, E., Mironenko, N., Pendinen, G. et al. (2010). A microsatellite and morphological assessment of the Russian National cultivated potato collection. Genetic Resources and Crop Evolution 57:1151-1164. http://dx.doi.org/10.1007/s10722-010-9554-8.

[18] Ghislain, M., Núnez, J., Herrera, M., Pignataro, J., Guzman, F. \& Bonierbale, M. (2009). Robust and highly informative microsatellite-based genetic identity kit for potato. Molecular 
Breeding 23: 377-388. https://doi.org/10.1007/s11032-0089240-0.

[19] Ghislain, M., Andrade, D., Rodríguez, F., Hijmans, R.J. \& Spooner, D.M. (2006). Genetic analysis of the cultivated potato Solanum tuberosum L. Phureja group using RAPDs and nuclear SSRs. Theoretical and Applied Genetics 113:15151527. https://doi.org/10.1007/s00122-006-0399-7.

[20] Ghislain, M., Spooner, D.M., Rodriguez, F., Villamon, F, Nunez, J., Vasquez, C. et al (2004). Selection of highly informative and user-friendly microsatellites (SSRs) for genotyping of cultivated potato. Theoretical and Applied Genetics 108:881-890. https://doi.org/10.1007/s00122-0031494-7.

[21] Ghislain, M., Trognitz, B., del Rosario Herrera, M., Solis, J., Casallo, G., Va 'squez, C. et al (2001). Genetic loci associated with field resistance to late blight in offspring of Solanum phureja and S. tuberosum grown under short-day conditions. Theoretical and Applied Genetics 103:433-442. https://doi.org/10.1007/s00122-001-0545-1.

[22] Ghislain, M., Zhang, D., Fajardo, D. \& Hijmans, R.J. (1999). Marker-assisted sampling of the cultivated Andean potato Solanum phureja collection using RAPD markers. Genetic Resources and Crop Evolution 46: 547-555. https://doi.org/10.1007/s00122-006-0399-7.

[23] Grover, A., Ramesh, B. \& Sharma, P.C. (2009). Development of microsatellite markers in potato and their transferability in some members of solanaceae. Physiology and Molecular Biology of Plants $15 \quad$ (4): $343-358$. https://doi.org/10.1007/s12298-009-0039-1.

[24] Halterman, D., Guenthner, J., Collinge, S., Butler, N. \& Douches, D. (2016). Biotech potatoes in the 21st century: 20 years since the first biotech potato. American Journal of Potato Research 93: 1-20. https://doi.org/10.1007/s12230015-9485-1.

[25] Hameed, A., Zaidi, S.S., Shakir, S. \& Mansoor, S. (2018). Application of new breeding technologies for potato improvement. Frontiers in Plant Science 9: 1-15. https://dx.doi.org/10.3389\%2Ffpls.2018.00925.

[26] Jaccard, P. (1908). Novelles researches sor la distribution floralis. Bulletin be la Societe ariddoise des sciences Nuturelles 44: 223-270.

[27] Jian, W., Lu, H., Wang, R.Y., He, M.M. \& Liu, Q.C. (2017). Genetic diversity and population structure of 288 potato (Solanum tuberosum L.) germplasms revealed by SSR and AFLP markers. Journal of Integrative Agriculture 16:24342443. https://doi.org/10.1016/S2095-3119(16)61619-2.

[28] Kawchuk, L.M., Lynch, D.R., Thomas, J., Penner, B., Sillito, D. \& Kulcsar, F. (1996). Characterization of Solanum tuberosum simple sequence repeats and application to potato cultivar identification. American Journal of Potato 73:325335. https://doi.org/10.1007/BF02849164.

[29] Komy, M.H., Saleh, A.A. \& Molan, Y.Y. (2012). Molecular characterization of early blight disease resistant and susceptible potato cultivars using random amplified polymorphic DNA (RAPD) and simple sequence repeats (SSR) markers. African Journal of Biotechnology 11(1): 37-45. https://www.ajol.info/index.php/ajb/article/view/93040.

[30] Liu, K. and Muse, S.V. (2005). Power Marker: Integrated analysis environment for genetic marker data. Bioinformatics 21: 2128-2129. https://doi.org/10.1093/bioinformatics/bti282.

[31] Ma, X., Mau, M. \& Sharbel, T.F. (2017). Genome editing for global food security. Trends in Biotechnology 36 123-127. https://doi.org/10.1016/j.tibtech.2017.08.004.

[32] Milbourne, D., Meyer, R., Collins, A., Ramsay, L., Gebhardt, C. \& Waugh, R. (1998). Isolation, characterization and mapping of simple sequence repeat loci in potato. Molecular Gene in Genetics 259:233-246. https://doi.org/10.1007/s004380050809.

[33] Moisan-Thiery, M., Marhadour, S., Kerlan, M.C., Dessenne, N., Perramant, M., Gokelaere T et al. (2005) Potato cultivar identification using simple sequence repeats markers (SSR). Potato Research 48:191-200. https://doi.org/10.1007/BF02742376.

[34] Provan, J., Powell, W. \& Waugh, R. (1996). Microsatellite analysis of relationships within cultivated potato (Solanum tuberosum). Theoretical and Applied Genetics 92:1078-1084. https://doi.org/10.1007/BF00224052.

[35] Qiu, D., Morgan, C., Shi, J., Long, Y., Liu, J., Li, R., Zhuang, X., Wang, Y., Tan, X., Dietrich, E., Everett, C. et al. (2006), A comparative linkage map of oilseed rape and its use for QTL analysis of seed oil and erucic acid content. Theoretical and Applied $\quad$ Genetics $\quad 114(1)$ : 67-80. https://doi.org/10.1007/s00122-006-0411-2.

[36] Rocha, E.A., Paiva, L.V., de Carvelho, H.H. \& Guimaraes, C.T. (2010). Molecular characterization and genetic diversity of potato cultivars using SSR and RAPD markers. Crop Breeding and Applied Biotechnology 10: 204-210. https://doi.org/10.1590/S1984-70332010000300004.

[37] Saensuk, C., Wanchana, S., Choowongkomon, K., Wongpornchai, S., Kraithong, T., Imsabai, W., Chaichoompu, E., Ruanjaichon, V., Toojinda, T., Vanavichit, A. \& Arikit, S. (2016). De novo transcriptome assembly and identification of the gene conferring a Bpandan-like aroma in coconut (Cocos nucifera L.). Plant Science 252:324-334. https://doi.org/10.1016/j.plantsci.2016.08.014.

[38] Selkoe, K.A. \& Toonen, R.J. (2006). Microsatellites for ecologists: A practical guide to using and evaluating microsatellite markers. Ecological Letters 9:615-629. https://doi.org/10.1111/j.1461-0248.2006.00889.x.

[39] Sharma, V. \& Nandineni, M.R. (2014). Assessment of genetic diversity among Indian potato (Solanum tuberosum L.) collection using microsatellite and retrotransposon based marker systems. Molecular and Phylogenetic Evolution 73:1017. https://doi.org/10.1016/j.ympev.2014.01.003.

[40] Singh, R., Ong-Abdullah, M., Low, E.T., Manaf M., Rosli, R., Nookiah, R., Ooi, L.C., Chan, K.L. et al. (2013). Oil palm 
genome sequence reveals divergence of interfertile species in Old and New worlds. Nature 500(7462): 335-339. https://doi.org/10.1038/nature12309.

[41] Tabkhkar, N., Rabiei, B. \& Sabouri, A. (2012). Genetic diversity of rice cultivars by microsatellite markers tightly linked to cooking and eating quality. Australian Journal of Crop Science 6(6):980-985. https://www.researchgate.net/publication/265750644.

[42] Tillault, A.S. \& Yevtushenko, D.P. (2019). Simple sequence repeat analysis of new potato varieties developed in Alberta, Canada. Plant Direct 00:1-10. https://doi.org/10.1002/pld3.140.

[43] Tiwari, J.K., Singh, B.P., Gopal, J., Poonam, Patil, V.U. (2013). Molecular characterization of the Indian Andigena potato core collection using microsatellite markers. African Journal of Biotechnology 12(10): 1025-1033. https://www.ajol.info/index.php/ajb/article/view/127875.

[44] Varshney, R.K., Chabane, K., Hendre, P.S., Aggarwal, R.K. \& Graner, A. (2007). Comparative assessment of EST-SSR, ESTSNP and AFLP markers for evaluation of genetic diversity and conservation of genetic resources using wild, cultivated and elite barleys. Plant Science 173: 638-649. http://dx.doi.org/10.1016/j.plantsci.2007.08.010.

[45] Wang, J., Hou, L., Wang, R. \& Liu, Q.C. (2017). Genetic diversity and population structure of 288 potato (Solanum tuberosum L.) germplasms revealed by SSR and AFLP markers. Journal of Integrative Agriculture 16(11): 24342443. https://dx.doi.org/10.3389\%2Ffpls.2019.00139.

[46] Wu, Y., Yang, Y., Qadri, R., Iqbal, A., Li, J., Fan, H. \& Wu, Y. (2019). Development of SSR markers for Coconut (Cocos nucifera L.) by Selectively Amplified Microsatellite (SAM) and its applications. Tropical Plant Biology 12: 32-43. https://doi.org/10.1007/s12042-018-9215-1.

[47] Xia, W., Xiao, Y., Liu, Z., Luo, Y., Mason, A.S., Fan, H., Yang, Y., Zhao, S. \& Peng, M. (2014). Development of genebased simple sequence repeat markers for association analysis in Cocos nucifera. Molecular Breeding 34(2):525-535. https://doi.org/10.1007/s11032-014-0055-x.

[48] Xiaoyan, S., Chunzhi, Z., Li, Y., Shuangshuang, F., Quing, Y. \& Sanwen, H. (2016). SSR analysis of genetic diversity among 192 diploid potato cultivar. Horticulture Plant Journal 2(3): 163-171. https://dx.doi.org/10.1016/j.hpj.2016.08.006.

[49] Yang, X.S., Su, W.J., Wang, L.J., Lei, J., Chai, S.S. \& Liu, Q.C. (2015). Molecular diversity and genetic structure of 380 sweet potato accessions as revealed by SSR markers. Journal of Integrative Agriculture 14: 633-641. https://doi.org/10.1016/S2095-3119(14)60794-2.

[50] Zaheer, K. \& Akhtar, M.H. (2016). Potato production, usage, and nutrition-a review. Critical Reviews in Food Science and Nutrition 56: 711-721. https://doi.org/10.1080/10408398.2012.724479. 